\title{
Acidified Biochar Confers Improvement in Quality and Yield Attributes of Sufaid Chaunsa Mango in Saline Soil
}

\author{
Javed Iqbal ${ }^{1}$, Sidra Kiran ${ }^{2}$, Shabir Hussain ${ }^{3}$, Rana Khalid Iqbal ${ }^{4}{ }^{\circledR}$, Umber Ghafoor ${ }^{5}$, Uzma Younis ${ }^{6}$, \\ Tayebeh Zarei ${ }^{7}$ (D), Misbah Naz ${ }^{8}$, Sevda Ghasemi Germi ${ }^{9}$, Subhan Danish 10,11,*(D), Mohammad Javed Ansari ${ }^{12}$ (D) \\ and Rahul Datta $11, *$ (D)
}

Citation: Iqbal, J.; Kiran, S.; Hussain, S.; Iqbal, R.K.; Ghafoor, U.; Younis, U.; Zarei, T.; Naz, M.; Germi, S.G.; Danish, S.; et al. Acidified Biochar Confers Improvement in Quality and Yield Attributes of Sufaid Chaunsa Mango in Saline Soil. Horticulturae 2021, 7, 418. https://doi.org/10.3390/ horticulturae7110418

Academic Editors: Michailidis Michail and Georgia Tanou

Received: 7 September 2021

Accepted: 14 October 2021

Published: 20 October 2021

Publisher's Note: MDPI stays neutra with regard to jurisdictional claims in published maps and institutional affiliations.

Copyright: (C) 2021 by the authors. Licensee MDPI, Basel, Switzerland. This article is an open access article distributed under the terms and conditions of the Creative Commons Attribution (CC BY) license (https:/ / creativecommons.org/licenses/by/ $4.0 /)$.
Mango Research Station, 6-km Basti Malook Road, Shujabad 59220, Pakistan; javedsaqi@gmail.com Mango Research Institute, Old Shujabad Road, Multan 60000, Pakistan; cidrakiran@gmail.com

3 Department of Agronomy, Faculty of Agricultural Sciences and Technology, Bahauddin Zakaria University, Multan 60800, Pakistan; shabirhussain@bzu.edu.pk

4 Institute of Molecular Biology and Biotechnology, Bahauddin Zakariya University, Multan 60800, Pakistan; Khalid.iqbal@bzu.edu.pk

5 Pesticide Residue Laboratory, Kala Shah Kaku 39020, Pakistan; umbergh@gmail.com

6 Department of Botany, University of Central Punjab, Lahore 54590, Pakistan; uzmabotany@hotmail.com

7 Laboratory of Tropical and Mediterranean Symbioses, CIRAD, 34398 Montpellier, France; z.tayebe@yahoo.com

8 Institute of Environment and Ecology, School of The Environment and Safety Engineering, Jiangsu University, 301 Xuefu Road, Zhenjiang 212013, China; raymisbah@ymail.com

9 Department of Agronomy, Faculty of Agriculture and Natural Resources, Ardebil 5619911367, Iran; sevdaghasemi@gmail.com

10 Department of Soil Science, Faculty of Agricultural Sciences and Technology, Bahauddin Zakariya University, Multan 60000, Pakistan

11 Department of Geology and Pedology, Faculty of Forestry and Wood Technology, Mendel University in Brno, Zemedelska 1, 61300 Brno, Czech Republic

12 Department of Botany, Hindu College Moradabad (Mahatma Jyotiba Phule Rohilkhand University Bareilly), Moradabad 244001, India; mjavedansari@gmail.com

* Correspondence: sd96850@gmail.com (S.D.); rahulmedcure@gmail.com (R.D.)

Abstract: Mango fruit quality plays a significant role in fruit storage. It also directly affects the economic value of fruit in the national and international markets. However, deterioration of soil health due to low organic matter is a major hurdle for mango growers. Scientists suggest incorporation of organic matter. However, high temperature and low precipitation lead to oxidation of organic residues in soil. On the other hand, biochar is gaining the attention of growers due to its resistance against decomposition. It can improve soil physicochemical attributes. Limited literature is available regarding biochar effects on the quality attributes of mango. Therefore, the current study was planned to investigate the effects of acidified biochar on mango quality and yield attributes in alkaline soil. Five levels of biochar, i.e., 0, 5, 10, 20 and $40 \mathrm{Mg} / \mathrm{ha}$, were applied in a randomized complete block design (RCBD). Results showed that 20 and $40 \mathrm{Mg} /$ ha acidified biochar significantly enhanced fruit retention, sugar contents, ash contents and TSS of mango compared to control. A significant increase in mango fruit weight and yield per plant validated the efficacious role of $40 \mathrm{Mg} / \mathrm{ha}$ acidified biochar over control. Furthermore, the maximum significant decrease in fruit juice acidity signified the imperative functioning of $40 \mathrm{Mg} / \mathrm{ha}$ acidified biochar in alkaline soil. In conclusion, $40 \mathrm{Mg} / \mathrm{ha}$ acidified biochar application can improve mango quality and yield attributes in alkaline soil. More investigations on different soil types, climatic zones and mango varieties are recommended to declare $40 \mathrm{Mg} /$ ha acidified biochar as the best treatment for improvement in the quality and yield of mango fruit in alkaline soils.

Keywords: Mangifera indica L.; TSS; acidity; fruit retention; fruit weight 


\section{Introduction}

Mango (Mangifera indica L.) is a fresh fruit commodity of Pakistan. It is successfully cultivated in tropical and subtropical climates. In Punjab, the area under mango cultivation is 99,000 hectares that generate an annual production of 1,321,000 tons with an average yield of $13.34 \mathrm{t} / \mathrm{ha}$ [1]. Pakistan's main exportable mango varieties are Sindhri, Chenab Gold, Chaunsa SB, Sufaid Chaunsa and Azeem Chaunsa, with an export window from May to September. The supply window of various mango varieties is five months due to differences in their maturity as early, mid and late-season cultivars. Sufaid Chaunsa is cultivated in $16 \%$ area of the Punjab mango zone. It attained a good position in the high-end market like Japan, China and Singapore which demand large size fruit with good color development. Sufaid Chaunsa is a late-season mango cultivar that attains its horticultural maturity after 15 August in the Multan region, strengthening its good position for export to various destinations [2]. In terms of suitable soil type for mango cultivation, loamy and semi-heavy sandy soils are more suitable, and heavy soils, light sandy soils and saline soils or wetlands are unsuitable. The most suitable soil $\mathrm{pH}$ for mango cultivation is between 5.5 and 7 [3].

Soil salinity is a major constraint of agricultural soils. It causes a remarkable decline in crop productivity and yield $[4,5]$. Furthermore, high salinity also deteriorates the quality attributes, which significantly decreases agricultural commodity market value $[6,7]$. In Pakistan, inappropriate fertilizer and pesticide application, poor quality irrigation, mismanagement of cultural practices and high transpiration are major causes of salinization and conversion of productive agricultural land into nonproductive areas. Although salinity is considered a big hurdle for crop production, it can be managed by an integrated approach to initiate better plant growth with no visible salt injury on leaves. The high salt content in soil and irrigation water may result in stunted growth and plant height with the burning of leaf margins and tip [8-10]. On the other hand, there is a specific extent of tolerance of soil salinity levels by the specific Pakistani mango varieties. Sindhri is considered the most sensitive, and Langra is considered the most tolerant one. However, mango cv. Sufaid Chaunsa has moderate tolerance [11].

Most scientists suggest the application of acidified organic amendments for the mitigation of salinity stress under alkaline conditions. Biochar is one of such organic amendments. It is black carbon mass-produced by pyrolysis of wood, chip, leaf, stem, manure, etc., at a high temperature of $300-1000{ }^{\circ} \mathrm{C}$ [12]. Organic active biochar is considered a potential nutrient-rich amendment to increase soil porosity and cation exchange sites and hence provide a nutrient-rich environment for the plant [13]. Biochar applications improve the soil nutrient delivery system of plants by amendments of physical, chemical and biological properties [14,15]. Mobilization in soil $\mathrm{pH}$ and EC by applying acidified carbon are key factors that improve soil health [16]. The application of acidified carbon also improves the soil carbon contents, playing an imperative role in exchanging essential nutrients between soil solution and exchange site [17]. On the other hand, a significant increase in the fruit yield of crops due to biochar has already been reported in many studies [12,18-22]. Furthermore, biochar has also been identified as a low-cost technology. It can introduce high contents of stabilizing carbon at a minimum cost compared to manure and compost. Depending upon nutrient sorption ability, biochar addition also decreases the cost of inorganic fertilizers [23,24].

Therefore, the current study was conducted to cover the knowledge gap regarding acidified biochar impacts on the quality attributes of mango fruit. The study aimed to explore and select the effective application rate of acidified biochar to improve the quality attributes of mango cv. Sufaid Chaunsa grown in saline soils. It is hypothesized that the use of acidified biochar might improve the quality and yield of mango cv. Sufaid Chaunsa. 


\section{Materials and Methods}

\subsection{Experimental Site}

Two-year (2019-2020) field experiments were conducted based on a randomized complete block design (RCBD) using different levels of acidified biochar. The climatic data of the experimental site are provided in Figure 1.

\subsection{Soil Characteristics}

The soil was calcareous in nature with silt loam texture [25]. For textural analysis, hydrometer method was used. After determination of soil separates, USDA textural triangle was used for texture determination. For $\mathrm{pH}$ analysis, 1:1 soil and water paste was made, and then a pre-calibrated $\mathrm{pH}$ meter was used. The $\mathrm{pH}$ of soil was 8.25 [26]. Electrical conductivity (ECe) was $4.64 \mathrm{dS} \mathrm{m}^{-1}$. It was analyzed by taking soil extract and using a pre-calibrated (with $0.01 \mathrm{~N} \mathrm{KCl}$ solution) $\mathrm{EC}$ meter [27]. $\mathrm{CaCO}_{3}=7.51 \%$ [28], organic matter $(\mathrm{OM})=0.40 \%$ [29], total nitrogen $=0.0225 \%$ [30], available phosphorus $(\mathrm{P})=5.12 \mathrm{mg} / \mathrm{kg}$ dry soil [31], extractable potassium $(\mathrm{K})=132 \mathrm{mg} / \mathrm{kg}$ dry soil [32], extractable zinc $(\mathrm{Zn})=0.25 \mathrm{mg} / \mathrm{kg}$ dry soil and extractable boron $(\mathrm{B})=0.26 \mathrm{mg} / \mathrm{kg}$ dry soil [33].
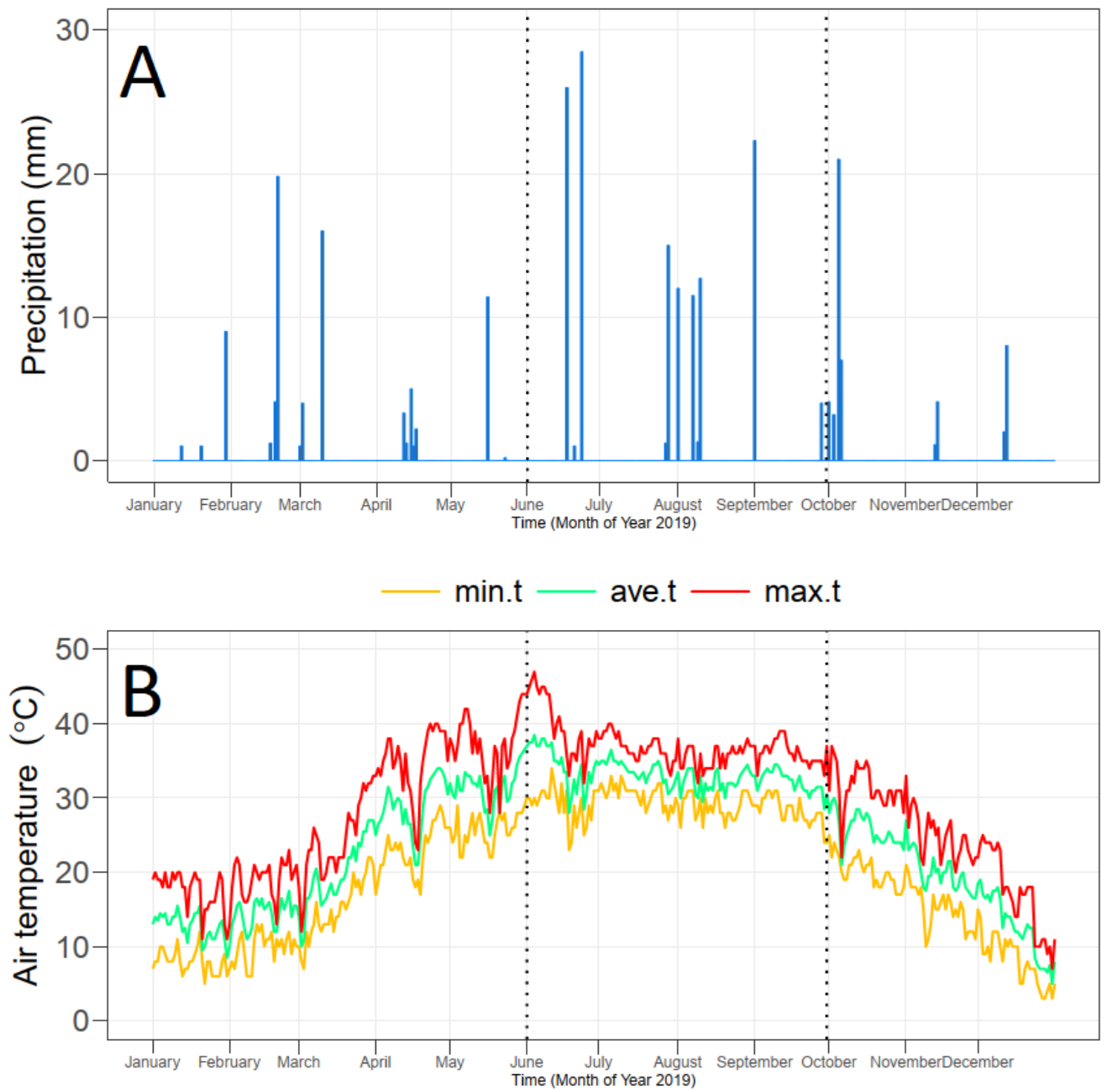

Figure 1. Cont. 

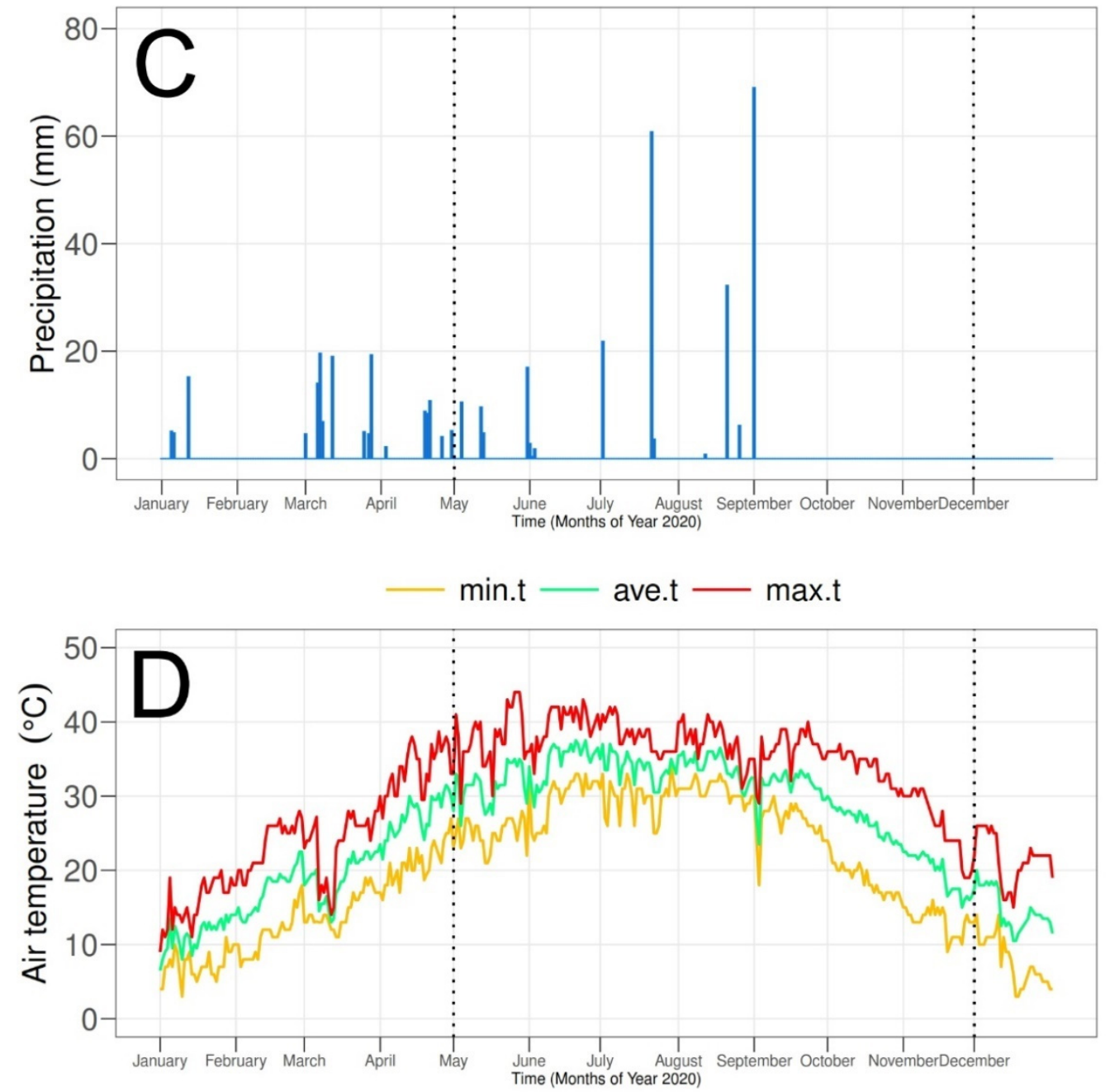

Figure 1. The daily minimum, maximum and average temperature and rainfall in Multan, Pakistan, during 2019 (A,B) and 2020 (C,D). The dotted lines show the duration of the mango crop.

\subsection{Biochar Preparations and Characterization}

Thermal pyrolysis was done using poultry manure to prepare acidified biochar. The pyrolysis was carried out at a low temperature of $355^{\circ} \mathrm{C}$ for two hours. After completion of pyrolysis and biochar cooling, the biochar was ground to $2 \mathrm{~mm}$ and then stored for investigational utilization [34,35]. For EC and $\mathrm{pH}, 1: 20(w / v)$ mixture of biochar and deionized water was used [34]. The phosphorus, sodium and potassium were analyzed by digesting biochar in di-acid $\left(\mathrm{HNO}_{3}: \mathrm{HClO}_{4}\right)$ [36]. Total nitrogen was analyzed on Kjeldhal's distillation apparatus [30]. The physicochemical characteristics of biochar were as follows: $\mathrm{pH}, 6.5$; EC, $5.2 \mathrm{dSm}^{-1}$; volatile matter, $17 \%$; ash content, $22 \%$; fixed carbon, $61 \%$; nitrogen, $1.2 \% w / w$; phosphorus, $0.75 \% w / w$; potassium, $3.24 \% w / w$; sodium, $1.52 \% w / w$.

\subsection{Treatment Plan and Mango Trees}

There were five treatments and four replications. Each treatment was applied to four healthy plants (9 years \pm 3 months) that make one block (594 sq. ft). In each corner, one tree was present. The treatments were control (no biochar), $5 \mathrm{Mg} / \mathrm{ha}$ biochar, $10 \mathrm{Mg} / \mathrm{ha}$ biochar, $20 \mathrm{Mg} / \mathrm{ha}$ biochar and $40 \mathrm{Mg} / \mathrm{ha}$ biochar. The biochar was mixed in the soil up to $2 \mathrm{ft}$ in depth. All the biochar was mixed manually in the soil by using a spade.

\subsection{NPK Application}

Based on the soil test of the study area, macronutrients N (as urea), P (diammonium phosphate) and $\mathrm{K}$ (potassium sulfate) were used in the ratio of 1.5, 1.0 and $1.0 \mathrm{~kg}$ per plant 
per year, respectively. Total required phosphorus used at the end of July. Nitrogen and potassium were added one-half at the end of July and the other one-half before the 1st week of February [2].

\subsection{Irrigation Practices}

The trench was made with a radius $1(\mathrm{r} 1)=12 \mathrm{ft}$ and radius $2(\mathrm{r} 2) 14 \mathrm{ft}$ apart from the main trunk of the tree. The depth of the trench was $2 \mathrm{ft}$. Eight irrigation treatments were applied on each tree with trench during the mango growing period at the experimental site.

\subsection{Analysis of Yield Attributes}

During the fruiting season, yield attributes such as fruit retention, fruit weight and fruit yield [2] were measured in the field.

\subsection{Fruit Retention}

To determine fruit retention percentage (the mustard stage to the marble stage of fruit), the area of $1.0 \mathrm{~m}^{2}$ was marked from four equal sides of the mango tree. The collection of fruit retention data was carried out after each month for three months.

\subsection{Fruit Weight}

Immediately after harvest, before fruit ripening, the fruit weight $(\mathrm{g})$ per tree was measured by a top-loading sensitive balance.

\subsection{Fruit Yield}

Every year at the time of fruit harvest, mango fruits were selected from the marked area on each mango tree, and the average fruit yield $(\mathrm{kg} /$ tree) was determined by the following formula:

Fruit Yield $(\mathrm{kg} /$ tree $)=$ Average weight of each tree fruit $\times$ Average number of fruits

\subsection{Soluble Sugars}

To determine soluble sugar, extraction of $0.1 \mathrm{~g}$ of mango sample was carried out using ethanol $(80 \%)$ with incubation at $60^{\circ} \mathrm{C}$ for $6 \mathrm{~h}$. The extracted solution $(1 \mathrm{~mL})$ was mixed with anthrone reagent $(6 \mathrm{~mL})$ in a test tube, and then the mixture was heated in boiling water for $10 \mathrm{~min}$. After this, test tubes were immediately cooled in an ice bath (10 min) and incubated at a temperature of $25^{\circ} \mathrm{C}$ for $20 \mathrm{~min}$. A spectrophotometer was used to observe solution absorbance at $625 \mathrm{~nm}$. Soluble sugar was calculated from the standard curve drawn by using standard solutions of sugar following the above method [37].

\subsection{Acidity}

A fresh mango juice sample was titrated to determine the percentage of citric acid in mango. For this determination, titration of the juice sample ( $\mathrm{pH} 8.2)$ was carried out with $0.1 \mathrm{~N} \mathrm{NaOH}$ (sodium hydroxide) as illustrated by Ranganna [38].

$$
\text { Acidity }(\%)=\left(\frac{\text { Volume of } 0.1 \mathrm{~N} \mathrm{NaOH}(\mathrm{mL}) \times 0.067}{\text { Volume of Juice }(\mathrm{mL})}\right) \times 100
$$

\subsection{Ash Content}

The percentage of fruit ash content was calculated according to Mclaughlin [39]. For ash content determination, $5 \mathrm{~g}$ of fruit sample was taken in the crucible. The crucible was kept at $550{ }^{\circ} \mathrm{C}$ in a muffle furnace for $30 \mathrm{~min}$ under aerobic conditions. After $30 \mathrm{~min}$, the crucible was removed from the furnace and immediately weighed on a digital balance. The percentage of ash content was calculated by the following formula:

$$
\text { Ash content }(\%)=\frac{(\text { Fruit sample fresh weight }(5 \mathrm{~g})-\text { Sample weight after furnace })}{\text { Weight after Muffle furnace }} \times 100
$$




\subsection{Total Soluble Solids (TSS)}

Fresh mango juice was used to determine total soluble solids (TTS) by digital hand refractometer (model SELECT045, Medline Scientific Ltd., Chalgrove OX44 7XZ, UK). For this, $20 \mathrm{~g}$ pulp from each fruit was homogenized in distilled water $(80 \mathrm{~mL})$ for $60 \mathrm{~s}$. After that, $1 \mathrm{~mL}$ of homogenate mixture was transferred to a refractometer for TSS analysis.

\subsection{Statistical Analysis}

Statistical analysis was conducted and graphs were made for each of the yield (fruit retention, fruit weight, fruit yield) and quality (soluble sugar, acidity, ash content, TTS) parameters of mango trees by using OriginPro 2021 statistical software program [40]. The treatments were compared using the Fisher LSD test.

\section{Results and Discussion}

\subsection{Fruit Retention}

The use of biochar (BC) significantly affects fruit retention (FR) (Figure 2A). Application of 20 and $40 \mathrm{Mg} / \mathrm{ha}$ of $\mathrm{BC}$ significantly improved retention of mango fruit compared to control treatment. No significant change in FR was noted when 5 and $10 \mathrm{Mg} / \mathrm{ha}$ of $\mathrm{BC}$ were applied (Figure 2B). Increased fruit retention by BC could be attributed to its role in enhancing nutrient uptake, photosynthetic efficiency and source-sink relationship and its antagonistic effect on transpiration and respiration [41]. Due to these enhancements in growth and physiological attributes of the plant, this fruit retention also leads towards an increase in the yield of the mango plant. Better uptake of boron in mango leaves improves the synthesis of auxin in the fruit petiole. Such enhancement in the biosynthesis of auxin strengthens the fruit petiole and thus increases fruit retention [42]. A high concentration of ethylene causes premature aging and rotting of fruits [42]. Biochar application also played an imperative role in the alleviation of different abiotic stresses, which decreases endogenous stressor ethylene [13,43-45]. Many catalytic activities during biochemical reactions of mango trees also trigger the dropping of premature fruits. Balanced uptake of potassium can control these catalytic actions, significantly improving fruit retention [46,47]. Such improvement in B and $\mathrm{K}$ was also observed in the nutrient concentrations of leaves in the current study.

\subsection{Fruit Weight}

Results showed that different levels of applied BC significantly affected mango fruit weight. The highest rate of $\mathrm{BC}(40 \mathrm{Mg} / \mathrm{ha})$ showed a significant effect in improving the weight of the fruit over control (Figure 3A). Figure 3B shows the statistically significant changes in fruit weight due to the application of different rates of $\mathrm{BC}$. Biochar can cause increases in plant growth and physiological attributes in terms of nutrient uptake and more photosynthesis [48-51] and therefore cause a significant increase in fruit weight; in the present study, the impact of treatments on fruit weight (FW) was significant. Jayappa et al. [52] have reported that BC effectively increases plant growth and mango fruit weight through changing plant root structure and improving water and nutrient uptake. According to Dutta [53] and Baieai [46], the better uptake of nutrients plays an imperative role in increasing the fruit weight.

\subsection{Fruit Yield}

According to the results of the analysis of variance, it was observed that with increasing the rates of $\mathrm{BC}$, fruit yield showed a significant increase, and the highest and lowest fruit yields were obtained from the application of $40 \mathrm{Mg} / \mathrm{ha}$ of $\mathrm{BC}$ and control, respectively (Figure 4A). As shown in Figure 4B, the results indicate the significant $(p<0.05)$ effects of $B C$ applications. In the present study, the increase in fruit yield due to the use of $B C$ could be attributed to an improvement in plant water and nutrient status, which causes an increase in leaf longevity and production of more photosynthetic material for transfer to sinks and increasing flowering period and flower durability [52,54,55]. Greater flower 
production means greater fruit yield in terms of fruit retention, thickness and weight. Ram et al. [56] reported improved yield of mango fruit (134.64 kg/tree) and total soluble solids contents in fruit $\left(24.93^{\circ}\right.$ Brix) as a result of the use of soil amendments. According to the observed results, fruit yield has a positive correlation with $B C$, sugar content, total solid sugars and ash content and a negative correlation with acidity. Better uptake of $\mathrm{K}$ and B helped to improve phyto-assimilation and carbohydrate synthesis [57].
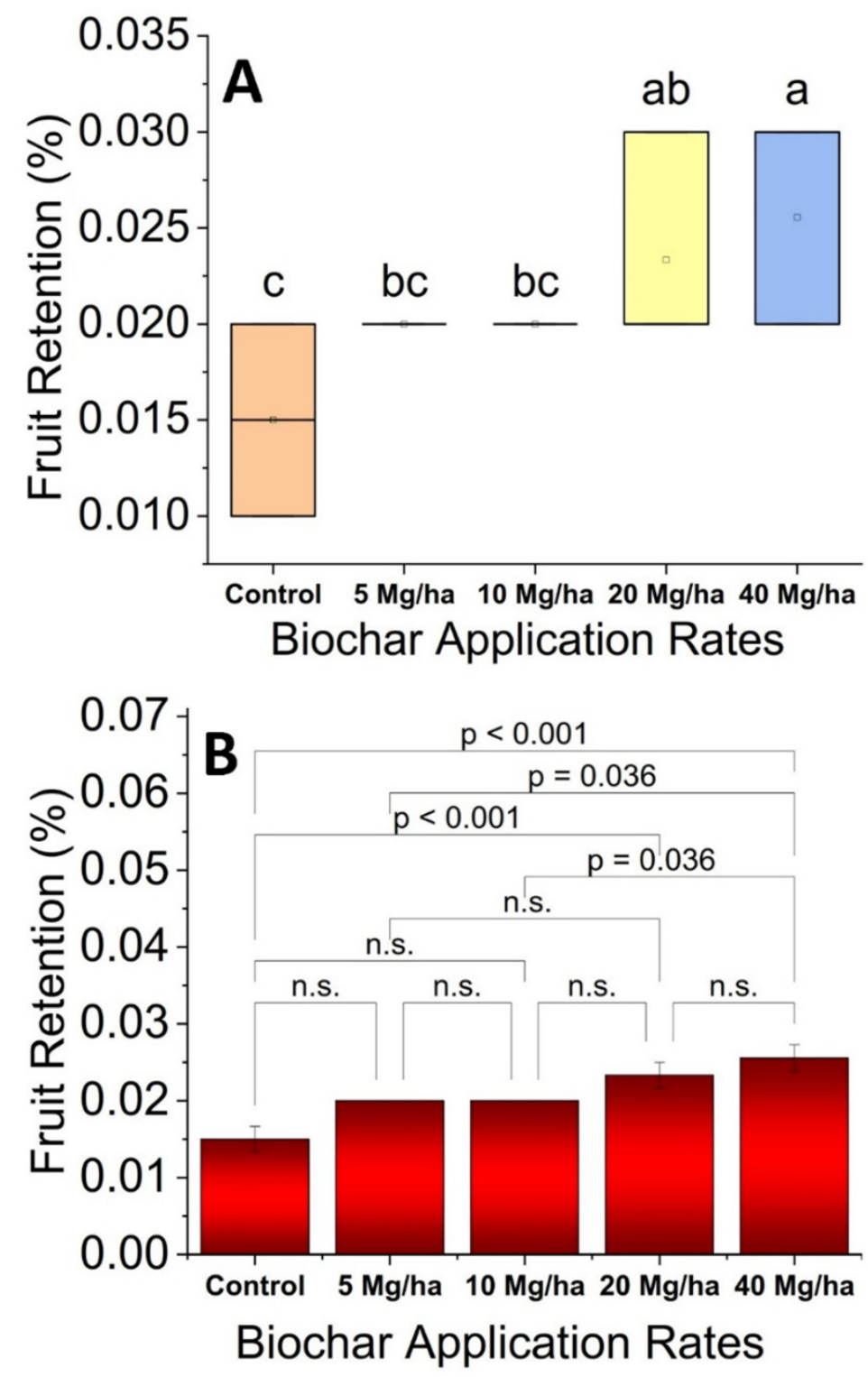

Figure 2. Effect of different biochar application rates on mango fruit retention. Bars are mean of 9 replicates. Different letters show a significant difference at $p \leq 0.05$ (A). The probability value hierarchy for fruit retention is provided in (B). 

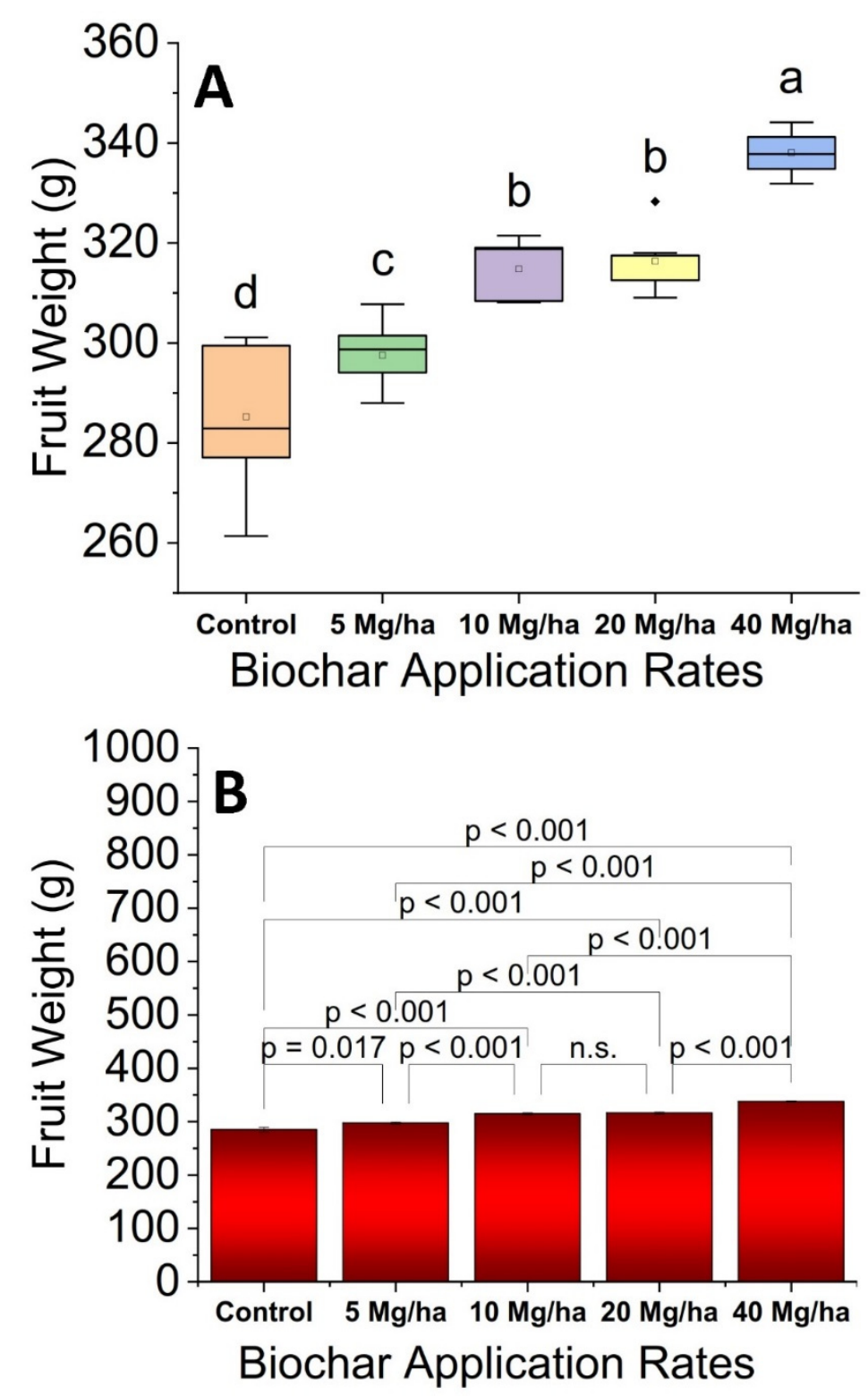

Figure 3. Effect of different biochar application rates on mango fruit weight. Bars are mean of 9 replicates. Different letters show a significant difference at $p \leq 0.05$ (A). The probability value hierarchy for fruit weight is provided in (B).

\subsection{Sugar Contents}

Fruit quality was also affected by the BC different levels and showed a significant upward trend. The highest fruit sugar content was obtained from the treatment of $40 \mathrm{Mg} / \mathrm{ha}$, which did not show a statistically significant difference with the level of $20 \mathrm{Mg} / \mathrm{ha}$; the lowest sugar content was observed for the control treatment, which had no statistical difference from the level of $5 \mathrm{Mg} /$ ha (Figure 5A,B). According to Tohidloo and Souri [58], plants use both active and passive mechanisms for the better uptake of B. However, under deficiency of B, xylem uptake is the most common pathway. Sugar alcohols, i.e., sorbitol and mannitol, also help in the re-translocation of $B$, thus helping in the alleviation of $B$ deficiency. One of the reasons for the increase insugar content of fruit with BC is better access to water and nutrients by plants $[15,59]$. Thisaffects the plant's structure and activity, and increasing leaf area and production of more carbohydrates led to an increase in the fruit sugar content [14]. The correlation results show a negative relationship between sugar content and the acidity of mango fruit. 

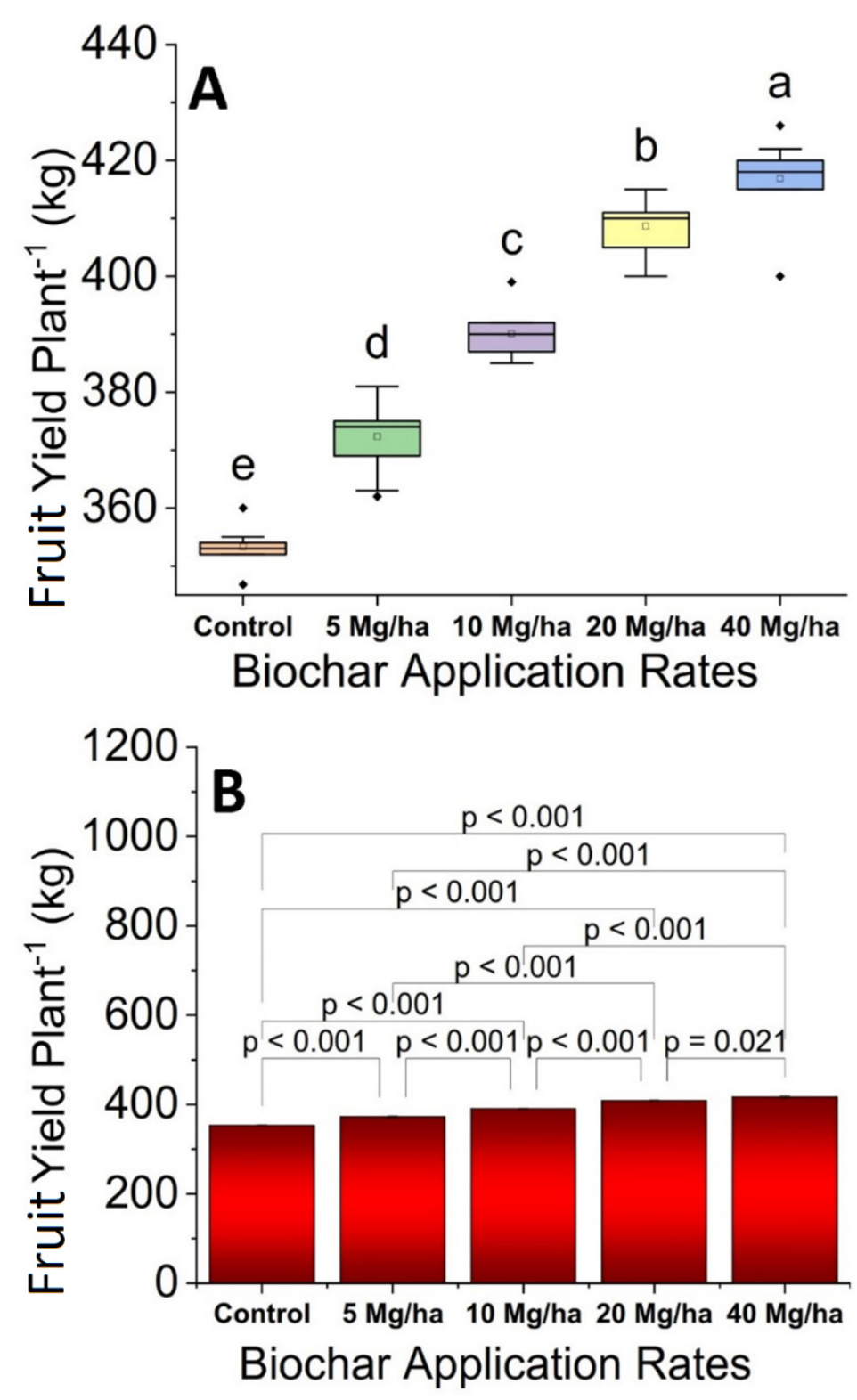

Figure 4. Effect of different biochar application rates on mango fruit yield per plant. Bars are mean of 9 replicates. Different letters show a significant difference at $p \leq 0.05$ (A). Probability value hierarchy for fruit yield per plant is provided in (B).

\subsection{Acidity}

Acidity is one of the criteria for measuring the quality and durability of fruit. All levels of BC decreased fruit acidity compared to the control; the lowest fruit acidity (12\%) was obtained from the $40 \mathrm{Mg} /$ ha treatment, and the highest fruit acidity (21\%) was found for the control treatment (Figure 6A). According to the results obtained, there were significant $(p<0.05)$ differences between treatments (Figure 6B). Results of Pearson correlation indicated that fruit acidity has no positive correlation with other traits. BC modifies fruit quality by reducing the $\mathrm{H}^{+}$activity in the rhizosphere and increasing the $\mathrm{pH}$ in the plant's root environment $[60,61]$, followed by soil fertility and moisture, and changes the ratio of acid to fruit sugar by reducing fruit acidity [62]. 

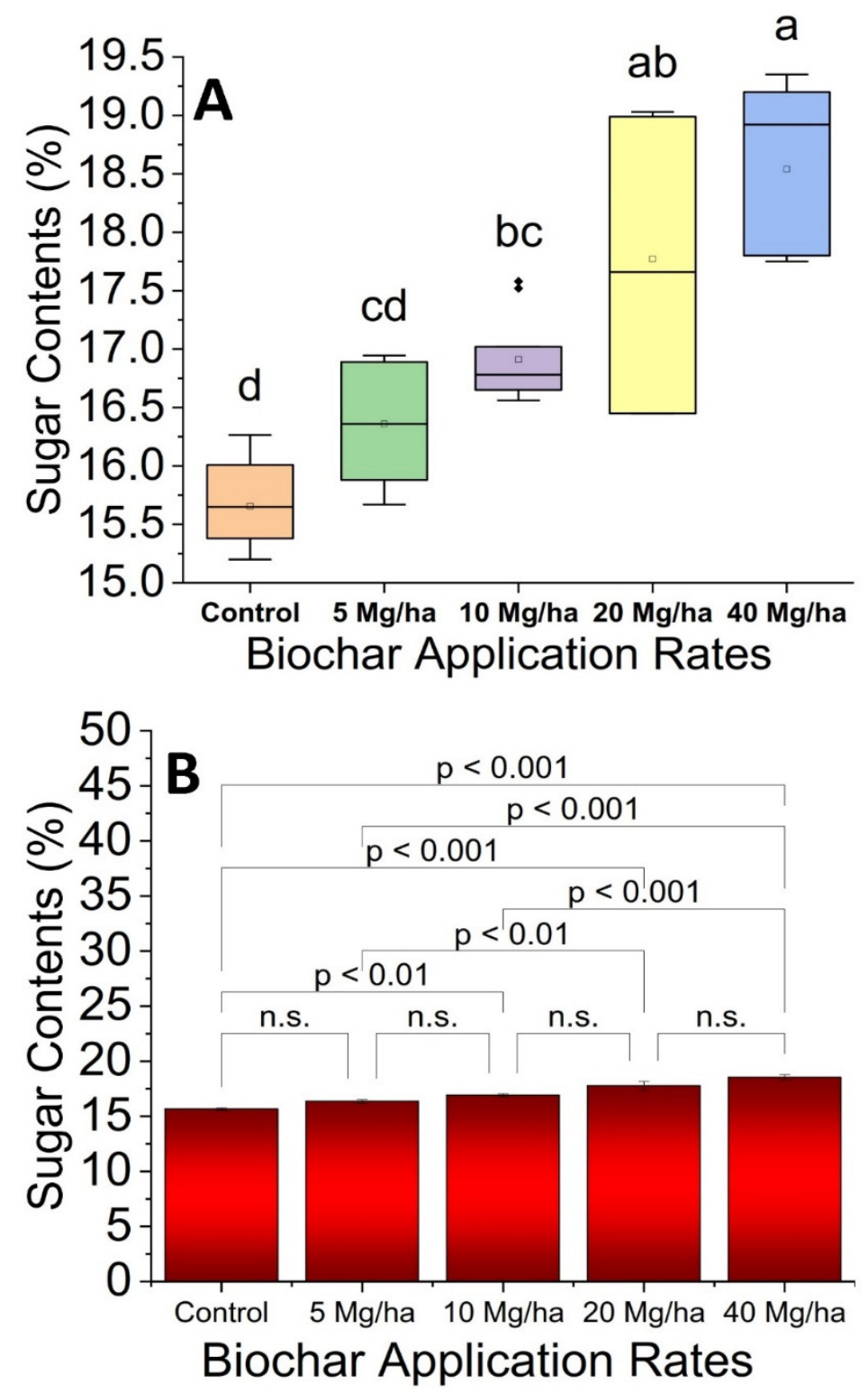

Figure 5. Effect of different biochar application rates on mango fruit sugar contents. Bars are mean of 9 replicates. Different letters show a significant difference at $p \leq 0.05$ (A). Probability value hierarchy for fruit sugar contents is provided in (B).

\subsection{Ash Contents}

The ash content is a measurement of the total inorganic matter of the fruit. The results indicated that the highest ash contents were obtained with the application rates of 20 and $40 \mathrm{Mg} /$ ha $\mathrm{BC}$, which were not significantly different from each other. The lowest ash content belonged to the control treatment (Figure 7A). This increase in ash content may be due to the positive role of biochar in improving the nutrient status of the fruits due to mineral ion translocation and accumulation $[63,64]$. In ash contents, no significant changes were observed between 20 and $40 \mathrm{Mg} / \mathrm{ha}$ (Figure 7B). Because ash content includes minerals, that's why increase in ash content enhanced the more nutrients uptake in plant $[34,65]$. Ash content had a significant positive correlation with other traits except for acidity. 
a
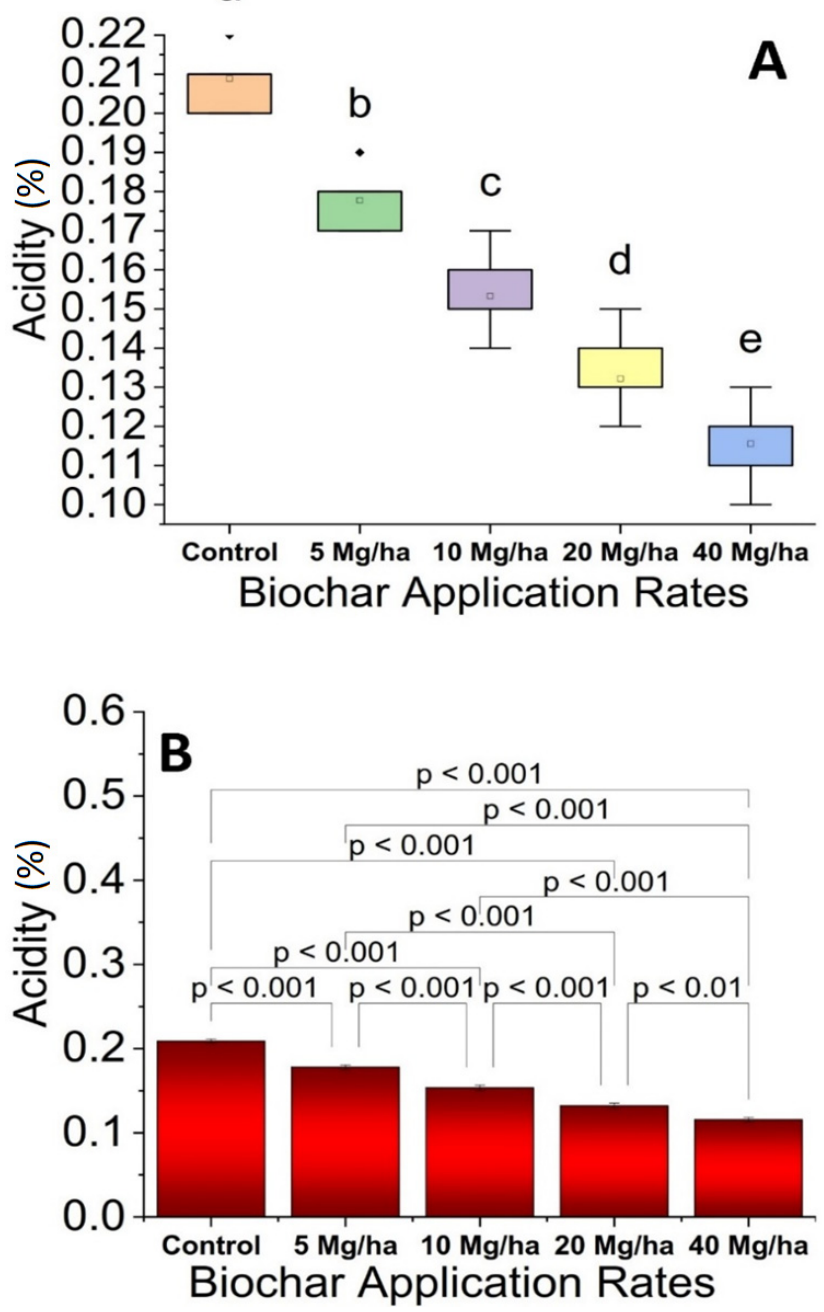

Figure 6. Effect of different biochar application rates on mango fruit juice acidity. Bars are mean of 9 replicates. Different letters show a significant difference at $p \leq 0.05$ (A). Probability value hierarchy for fruit juice acidity is provided in (B).

\subsection{Total Soluble Solids (TSS) Content}

The total soluble solids (TSS)content is an important characteristic for products that are sold fresh since consumers prefer sweeter fruits [66]. With increasing BC application rates, TSS showed an increasing trend. This increase was more evident in $40 \mathrm{Mg} / \mathrm{ha}$, with no statistically significant difference between 40, 20 and $10 \mathrm{Mg} / \mathrm{ha}$ BC for TSS (Figure 8A). The $5 \mathrm{Mg} /$ ha BC treatment showed a significant difference in TSS compared to control (Figure $8 \mathrm{~B}$ ). The addition of $\mathrm{BC}$ with a significant reduction in soil compaction provides a large soil area in terms of water and nutrients reaching the plant roots. It converts polysaccharides and starch into simple sugars, increasing the fruit's storage [67]. AboOgiala [68], in a study on the impact of wood sawdust BC on the quality traits of banana fruit, observed that $20 \mathrm{Mg} / \mathrm{ha} \mathrm{BC}$ addition to saline soils improved sugar contents, total solid sugars, starch and mineral content of leaves. 

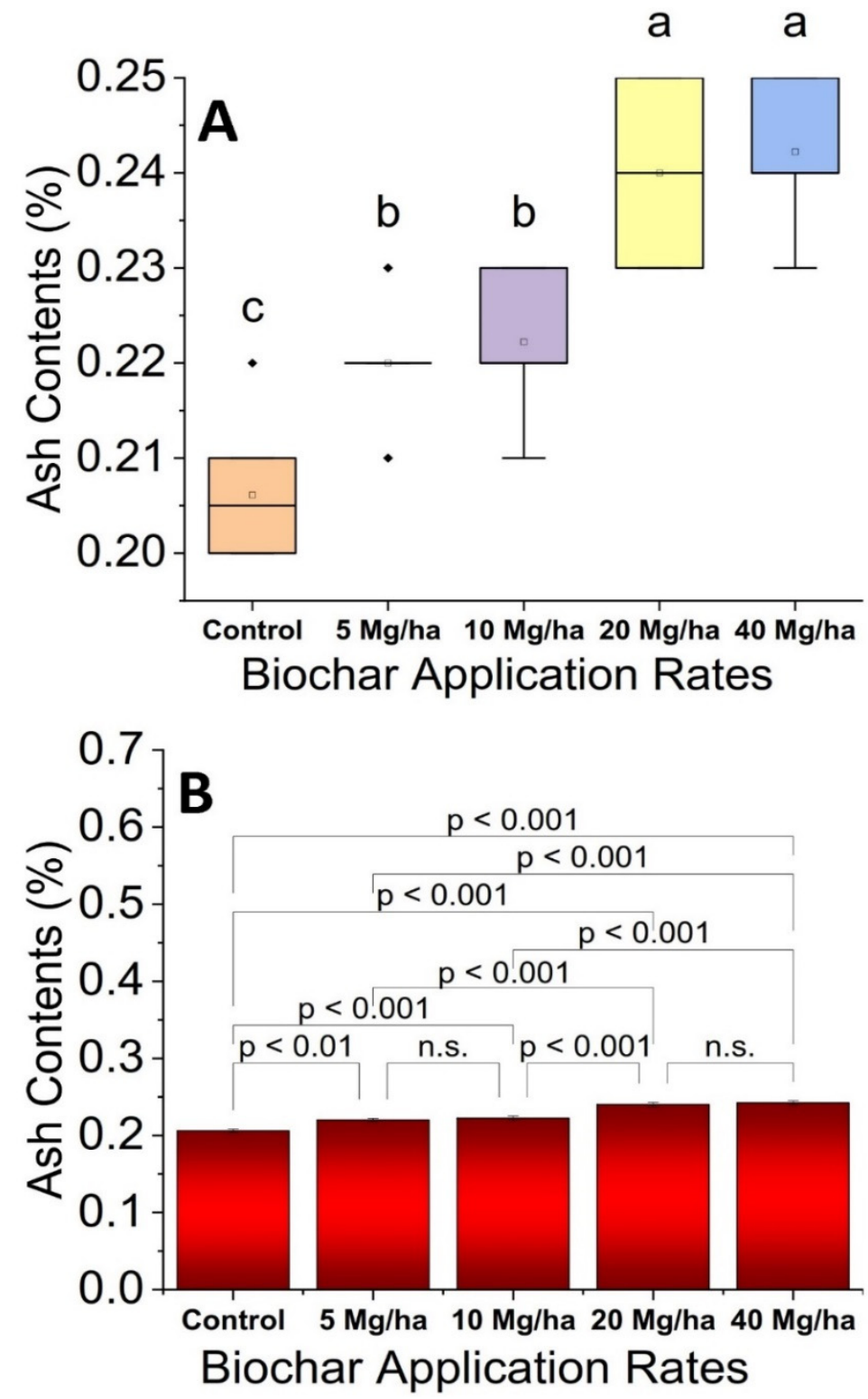

Figure 7. Effect of different biochar application rates on mango fruit ash contents. Bars are mean of 9 replicates. Different letters show a significant difference at $p \leq 0.05$ (A). Probability value hierarchy for fruit ash contents is provided in (B).

\subsection{Nutrient Concentrations}

The effect of treatments on nitrogen $(\mathrm{N})$, phosphorus $(\mathrm{P})$, potassium $(\mathrm{K})$ and boron (B) was significant. Increasing the level of biochar enhanced the uptake of N, P, K and B. For nitrogen, $20 \mathrm{Mg} / \mathrm{ha}$ biochar remained significantly best among all biochar application rates compared to control. Compared to control, no significant change in $\mathrm{N}$ was noted when $5 \mathrm{Mg} /$ ha biochar was applied. For $\mathrm{P}, \mathrm{K}$ and $\mathrm{B}, 20 \mathrm{Mg} / \mathrm{ha}$ biochar also remained significantly better among all biochar application rates. Compared to control, maximum increases of $21 \%, 50 \%, 26 \%$ and $40 \%$ were observed in $\mathrm{N}, \mathrm{P}, \mathrm{K}$ and $\mathrm{B}$, respectively, when $20 \mathrm{Mg} /$ ha biochar was applied (Table 1). Under alkaline conditions, the application of acidified carbon improved physiochemical conditions. Such improvements in soil pH, EC and organic matter mobilized the immobile nutrients of soil, thus enhancing their uptake in the plants $[16,69]$. 

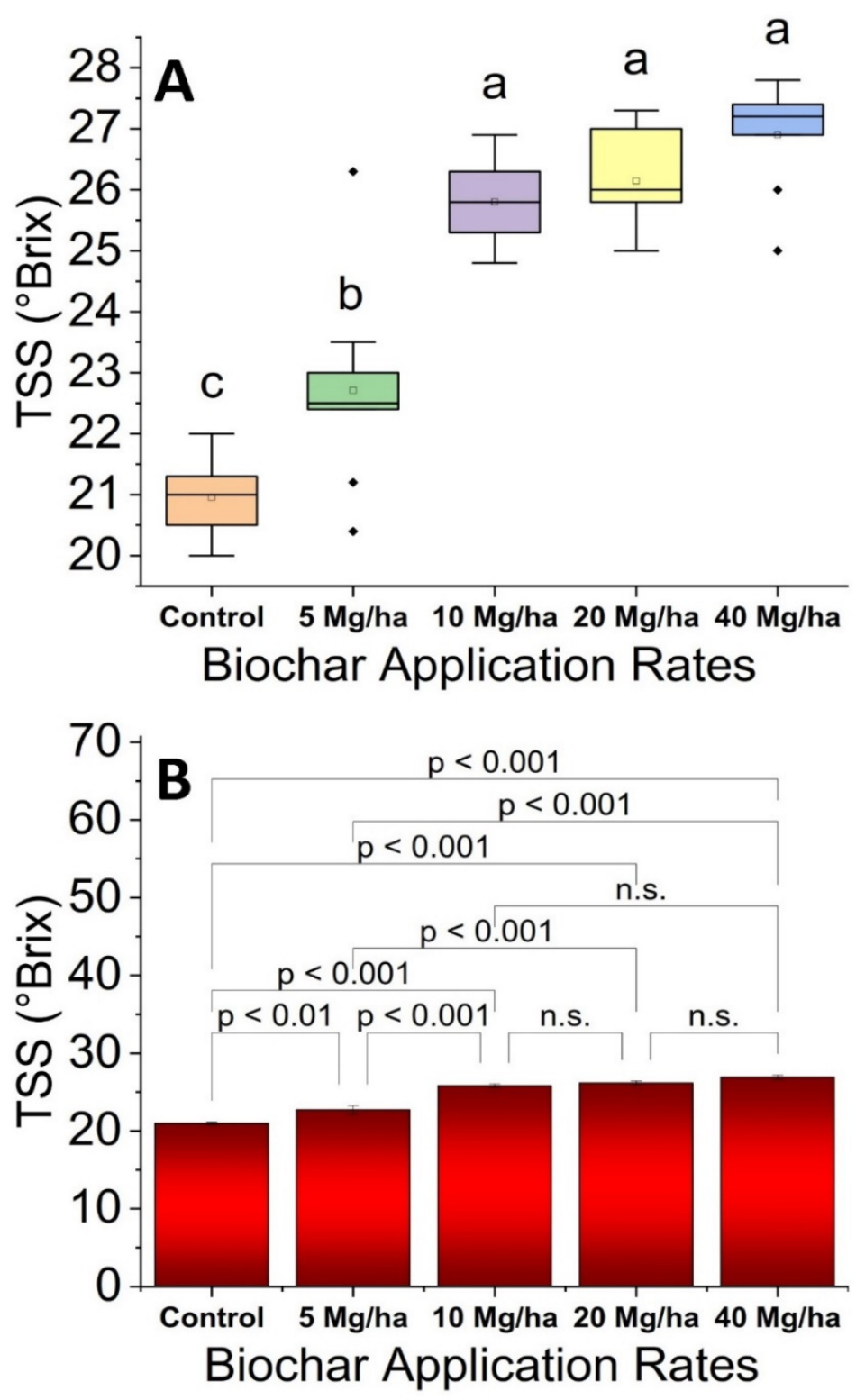

Figure 8. Effect of different biochar application rates on mango fruit TSS. Bars are mean of 9 replicates. Different letters show a significant difference at $p \leq 0.05$ (A). Probability value hierarchy for fruit TSS is provided in (B).

Table 1. Effect of different biochar application rates on leaf nutrient concentrations.

\begin{tabular}{ccccc}
\hline Treatments & Nitrogen & Phosphorus & Potassium & Boron \\
\hline Control & $0.75 \pm 0.03 \mathrm{~d}$ & $0.08 \pm 0.001 \mathrm{c}$ & $0.35 \pm 0.003 \mathrm{~d}$ & $15.23 \pm 0.10 \mathrm{e}$ \\
\hline $5 \mathrm{Mg} /$ ha biochar & $0.77 \pm 0.04 \mathrm{~d}$ & $0.11 \pm 0.007 \mathrm{~b}$ & $0.35 \pm 0.004 \mathrm{~d}$ & $16.11 \pm 0.12 \mathrm{~d}$ \\
\hline $10 \mathrm{Mg} /$ ha biochar & $0.85 \pm 0.01 \mathrm{c}$ & $0.11 \pm 0.003 \mathrm{~b}$ & $0.38 \pm 0.001 \mathrm{c}$ & $19.74 \pm 0.30 \mathrm{~b}$ \\
\hline $15 \mathrm{Mg} /$ ha biochar & $0.88 \pm 0.01 \mathrm{~b}$ & $0.11 \pm 0.005 \mathrm{~b}$ & $0.40 \pm 0.003 \mathrm{~b}$ & $18.55 \pm 0.11 \mathrm{c}$ \\
\hline $20 \mathrm{Mg}$ /ha biochar & $0.91 \pm 0.02 \mathrm{a}$ & $0.12 \pm 0.002 \mathrm{a}$ & $0.44 \pm 0.005 \mathrm{a}$ & $21.32 \pm 0.15 \mathrm{a}$ \\
\hline
\end{tabular}

Means are average of 9 replicates \pm standard error. Different letters show a significant difference at $p<0.05$.

Pearson correlation indicates a significant positive correlation of total soluble sugar content with traits other than acidity. In all the attributes studied in pearson correlation acidity was significant netive in correlation (Figure 9). Arrows indicate each trait's loadings and the first two components, which comprised $89.3 \%$ of the total variation for seven traits. The percentages of total variance are represented by principal component 1 (PC1) and 
principal component 2 (PC2) (Figure 10). The analysis also showed that the acidity of fruit juice was opposite in direction and was distant from the other studied attributes. FR had the same direction as the group of other studied attributes, but it was distant from them.

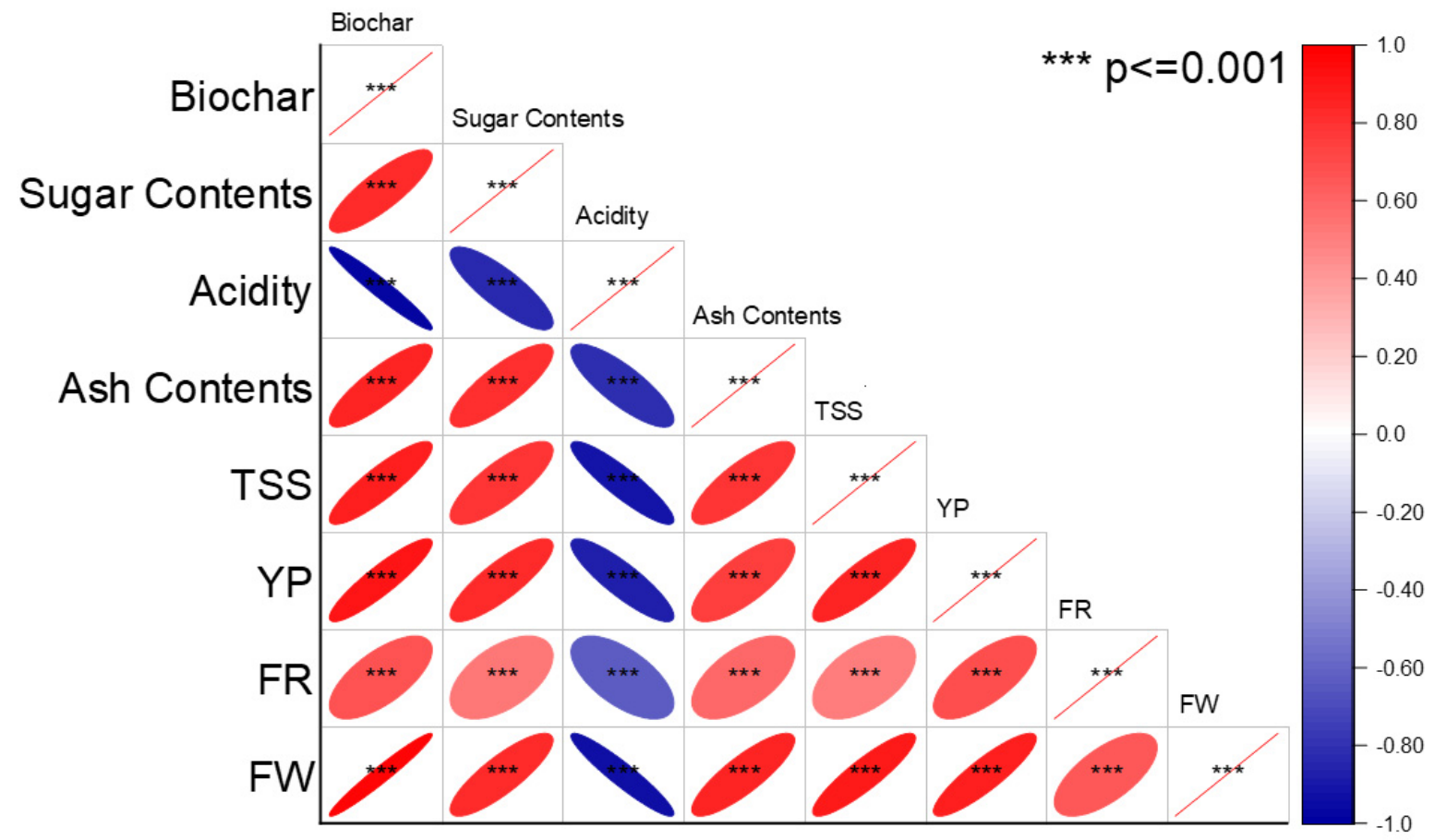

Figure 9. Pearson correlation for mango fruit attributes affected by different biochar application rates. Red color indicates positive correlation; blue color indicates negative correlation. Intensity of color shows the strength of correlation between attributes. TSS = total soluble solids; $\mathrm{YP}=$ yield per plant; FR = fruit retention; FW = fruit weight.

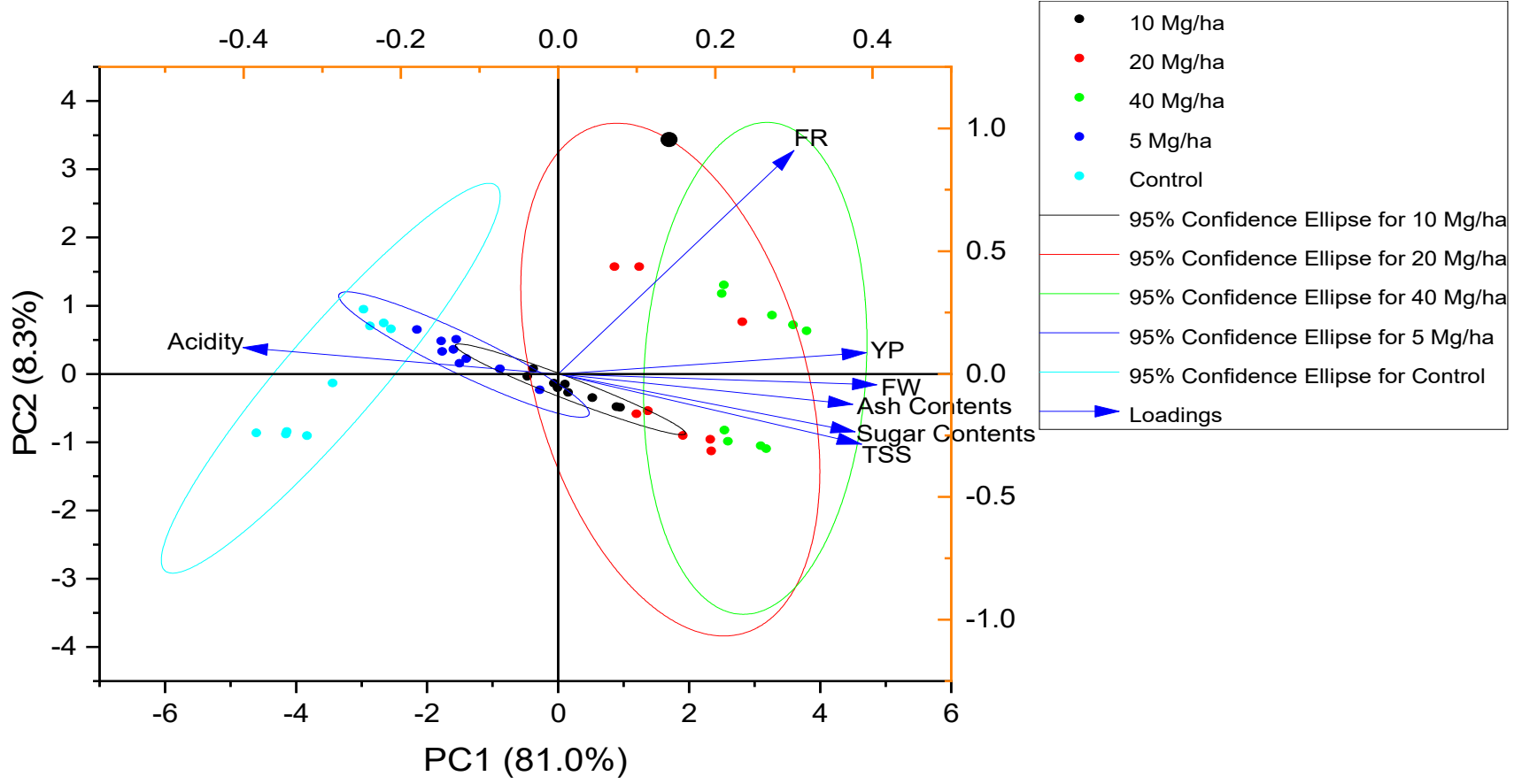

Figure 10. Principal component analysis for observed attributes of mango affected by different biochar application rates. 


\section{Conclusions}

It is concluded that acidified biochar can improve the yield of mango cv. Sufaid Chaunsa. Application of $40 \mathrm{Mg} /$ ha acidified biochar significantly increased sugar content, fresh weight and fruit retention when applied in salt-affected soils. Among the different levels of biochar application, we recommend the application level of $40 \mathrm{Mg} / \mathrm{ha}$ as the better treatment for decreasing the acidity of fruit juice of mango cv. Sufaid Chaunsa. Pearson correlation also showed that acidified biochar showed a significant positive correlation with all quality and yield attributes except fruit juice acidity (significant negative correlation). The PCA also validated the positive effects of acidified biochar on mango cv. Sufaid Chaunsa in saline soil. In the future, investigations considering different climatic zones, soil types and mango cultivars, along with cost analysis and effects of acidified biochar as a soil amendment on soil characteristics, are needed to declare $40 \mathrm{Mg} / \mathrm{ha}$ as the best treatment for improvement in yield and quality attributes of mango.

Author Contributions: Conceptualization, J.I., S.K., S.H. and R.K.I.; methodology, J.I., S.K., S.H. and R.K.I.; software, J.I., S.K., S.H. and R.K.I.; validation, J.I., S.K., S.H. and R.K.I.; formal analysis, J.I., S.K., S.H. and R.K.I.; investigation, J.I., S.K., S.H., R.K.I.; U.G.; M.N.; writing-original draft preparation, U.G., U.Y., T.Z., M.N., S.G.G. and S.D.; writing-review and editing, S.D., M.J.A. and R.D.; visualization, S.D., M.J.A. and R.D.; supervision, J.I., S.K., S.D. and R.D.; funding acquisition, S.D. and R.D. All authors have read and agreed to the published version of the manuscript.

Funding: Not applicable.

Institutional Review Board Statement: Not applicable.

Informed Consent Statement: Not applicable.

Data Availability Statement: Not applicable.

Conflicts of Interest: The authors declare no conflict of interest.

\section{References}

1. Murtaza, M.R.; Mehmood, T.; Ahmad, A.; Mughal, U.A. With and without intercropping economic evaluation of mango fruits: Evidence from Southern Punjab, Pakistan. Sarhad J. Agric. 2020, 36, 192-197. [CrossRef]

2. Bibi, F.; Ahmad, I.; Bakhsh, A.; Kiran, S.; Danish, S.; Ullah, H. Effect of Foliar Application of Boron with Calcium and Potassium on Quality and Yield of Mango cv. Summer Bahisht (SB) Chaunsa. Open Agric. 2019, 4, 98-106. [CrossRef]

3. Mirza, B.; Croley, C.R.; Ahmad, M.; Pumarol, J.; Das, N.; Sethi, G.; Bishayee, A. Mango (Mangifera indica L.): A magnificent plant with cancer preventive and anticancer therapeutic potential. Crit. Rev. Food Sci. Nutr. 2021, 61, 2125-2151. [CrossRef] [PubMed]

4. Chaves, M.M.; Flexas, J.; Pinheiro, C. Photosynthesis under drought and salt stress: Regulation mechanisms from whole plant to cell. Ann. Bot. 2009, 103, 551-560. [CrossRef] [PubMed]

5. Fageria, N.K.; Gheyi, H.R.; Moreira, A. Nutrient bioavailability in salt affected soils. J. Plant Nutr. 2011, 34, 945-962. [CrossRef]

6. Abbas, F. Analysis of a historical (1981-2010) temperature record of the Punjab Province of Pakistan. Earth Interact. 2013, 17, 1-23. [CrossRef]

7. Acosta-Motos, J.; Ortuño, M.; Bernal-Vicente, A.; Diaz-Vivancos, P.; Sanchez-Blanco, M.; Hernandez, J. Plant Responses to Salt Stress: Adaptive Mechanisms. Agronomy 2017, 7, 18. [CrossRef]

8. Di Caterina, R.; Giuliani, M.M.; Rotunno, T.; De Caro, A.; Flagella, Z. Influence of salt stress on seed yield and oil quality of two sunflower hybrids. Ann. Appl. Biol. 2007, 151, 145-154. [CrossRef]

9. El Rabey, H.A.; Al-Malki, A.L.; Abulnaja, K.O. Proteome Analysis of Date Palm (Phoenix dactylifera L.) under Severe Drought and Salt Stress. Int. J. Genom. 2016, 2016, 7840759. [CrossRef]

10. El-Mageed, T.A.A.; Semida, W.M.; El-Wahed, M.H.A. Effect of mulching on plant water status, soil salinity and yield of squash under summer-fall deficit irrigation in salt affected soil. Agric. Water Manag. 2016, 173, 1-12. [CrossRef]

11. Ahmed, N.; Khalid, S.; Grewal, A.G.; Ali, M.A.; Anjum, M.A.; Rahi, A.A.; Danish, S. Performance of mango scion cultivars under various levels of artificially induced salinity stress. Pak. J. Bot. 2020, 52, 1143-1158. [CrossRef]

12. Diatta, A.A.; Fike, J.H.; Battaglia, M.L.; Galbraith, J.M.; Baig, M.B. Effects of biochar on soil fertility and crop productivity in arid regions: A review. Arab. J. Geosci. 2020, 13, 595. [CrossRef]

13. Dawar, K.; Fahad, S.; Alam, S.S.; Khan, S.A.; Dawar, A.; Younis, U.; Danish, S.; Datta, R.; Dick, R.P. Influence of variable biochar concentration on yield-scaled nitrous oxide emissions, Wheat yield and nitrogen use efficiency. Sci. Rep. 2021, 11, 16774. [CrossRef] [PubMed]

14. Farhangi-Abriz, S.; Torabian, S. Effect of biochar on growth and ion contents of bean plant under saline condition. Environ. Sci. Pollut. Res. 2018, 25, 11556-11564. [CrossRef] [PubMed] 
15. Ali, S.; Rizwan, M.; Qayyum, M.F.; Ok, Y.S.; Ibrahim, M.; Riaz, M.; Arif, M.S.; Hafeez, F.; Al-Wabel, M.I.; Shahzad, A.N. Biochar soil amendment on alleviation of drought and salt stress in plants: A critical review. Environ. Sci. Pollut. Res. 2017, 24, 12700-12712. [CrossRef] [PubMed]

16. Sultan, H.; Ahmed, N.; Mubashir, M.; Danish, S. Chemical production of acidified activated carbon and its influences on soil fertility comparative to thermo-pyrolyzed biochar. Sci. Rep. 2020, 10, 595. [CrossRef]

17. Sadegh-Zadeh, F.; Parichehreh, M.; Jalili, B.; Bahmanyar, M.A. Rehabilitation of calcareous saline-sodic soil by means of biochars and acidified biochars. Land Degrad. Dev. 2018, 29, 3262-3271. [CrossRef]

18. Guo, L.; Yu, H.; Kharbach, M.; Zhang, W.; Wang, J.; Niu, W. Biochar improves soil-tomato plant, tomato production, and economic benefits under reduced nitrogen application in northwestern china. Plants 2021, 10, 759. [CrossRef]

19. Keabetswe, L.; Shao, G.C.; Cui, J.; Lu, J.; Stimela, T. A combination of biochar and regulated deficit irrigation improves tomato fruit quality: A comprehensive quality analysis. Folia Hortic. 2019, 31, 181-193. [CrossRef]

20. Agegnehu, G.; Srivastava, A.K.; Bird, M.I. The role of biochar and biochar-compost in improving soil quality and crop performance: A review. Appl. Soil Ecol. 2017, 119, 156-170. [CrossRef]

21. Brantley, K.; Savin, M.; Brye, K.; Longer, D. Pine Woodchip Biochar Impact on Soil Nutrient Concentrations and Corn Yield in a Silt Loam in the Mid-Southern U.S. Agriculture 2015, 5, 30-47. [CrossRef]

22. Akhtar, S.S.; Li, G.; Andersen, M.N.; Liu, F. Biochar enhances yield and quality of tomato under reduced irrigation. Agric. Water Manag. 2014, 138, 37-44. [CrossRef]

23. Jeffery, S.; Abalos, D.; Prodana, M.; Bastos, A.C.; Van Groenigen, J.W.; Hungate, B.A.; Verheijen, F. Biochar boosts tropical but not temperate crop yields. Environ. Res. Lett. 2017, 12, 53001. [CrossRef]

24. Jeffery, S.; Verheijen, F.G.A.; van der Velde, M.; Bastos, A.C. A quantitative review of the effects of biochar application to soils on crop productivity using meta-analysis. Agric. Ecosyst. Environ. 2011, 144, 175-187. [CrossRef]

25. Gee, G.W.; Bauder, J.W. Particle-size analysis. In Methods of Soil Analysis. Part 1. Physical and Mineralogical Methods; John Wiley \& Sons, Inc.: Madison, WI, USA, 1986; pp. 383-411. ISBN 978-0-89118-864-3.

26. Page, A.L.; Miller, R.H.; Keeny, D.R. Soil pH and lime requirement. In Methods of Soil Analysis; American Society of Agronomy; John Wiley \& Sons, Inc.: Madison, WI, USA, 1982; pp. 199-208.

27. Rhoades, J.D. Salinity: Electrical Conductivity and Total Dissolved Solids. In Methods of Soil Analysis, Part 3, Chemical Methods; Sparks, D.L., Page, A.L., Helmke, P.A., Loeppert, R.H., Soltanpour, P.N., Tabatabai, M.A., Johnston, C.T., Sumner, M.E., Eds.; Soil Science Society of America; John Wiley \& Sons, Inc.: Madison, WI, USA, 1996; Volume 5, pp. 417-435.

28. Loeppert, R.H.; Suarez, D.L. Carbonate and Gypsum. In Methods of Soil Analysis, Part 3, Chemical Methods; Soil Science Society of America; John Wiley \& Sons, Inc.: Madison, WI, USA, 2018; Volume 9, pp. 181-197.

29. Nelson, D.W.; Sommers, L.E. Total Carbon, Organic Carbon, and Organic Matter. In Methods of Soil Analysis: Part 2 Chemical and Microbiological Properties; Page, A.L., Ed.; American Society of Agronomy; Crop Science Society of America; Soil Science Society of America; John Wiley \& Sons, Inc.: Madison, WI, USA, 1982; pp. 539-579.

30. Bremner, M. Nitrogen-Total. In Methods of Soil Analysis Part 3. Chemical Methods-SSSA Book Series 5; Sparks, D.L., Page, A.L., Helmke, P.A., Loeppert, R.H., Soltanpour, P.N., Tabatabai, M.A., Johnston, C.T., Sumner, M.E., Eds.; John Wiley \& Sons, Inc.: Madison, WI, USA, 1996; pp. 1085-1121.

31. Kuo, S. Phosphorus. In Methods of Soil Analysis Part 3: Chemical Methods; Sparks, D.L., Page, A.L., Helmke, P.A., Loeppert, R.H., Soltanpour, P.N., Tabatabai, M.A., Johnston, C.T., Sumner, M.E., Eds.; John Wiley \& Sons, Ltd.: Madison, WI, USA, 1996; pp. 869-919.

32. Pratt, P.F. Potassium. In Methods of Soil Analysis: Part 2 Chemical and Microbiological Properties, 9.2; Norman, A.G., Ed.; John Wiley \& Sons, Ltd.: Madison, WI, USA, 1965; pp. 1022-1030.

33. Lindsay, W.L.; Norvell, W.A. A DTPA soil test for zinc, iron, manganese and copper. Soil Sci. Soc. Am. J. 1978, 42, 421-428. [CrossRef]

34. Qayyum, M.F.; Abid, M.; Danish, S.; Saeed, M.K.; Ali, M.A. Effects of various biochars on seed germination and carbon mineralization in an alkaline soil. Pak. J. Agric. Sci. 2014, 51, 977-982.

35. Danish, S.; Tahir, F.A.; Rasheed, M.K.; Ahmad, N.; Ali, M.A.; Kiran, S.; Younis, U.; Irshad, I.; Butt, B. Effect of foliar application of Fe and banana peel waste biochar on growth, chlorophyll content and accessory pigments synthesis in spinach under chromium (IV) toxicity. Open Agric. 2019, 4, 381-390. [CrossRef]

36. Miller, O. Nitric-Perchloric Acid Wet Digestion in an Open Vessel. In Reference Methods for Plant Analysis; Kalra, Y., Ed.; CRC Press: Washington, DC, USA, 1998; pp. 57-62.

37. Yemm, E.W.; Willis, A.J. The estimation of carbohydrates in plant extracts by anthrone. Biochem. J. 1954, 57, 508-514. [CrossRef]

38. Ranganna, S. Titratable Acidity; Ranganna, S., Ed.; Tata McGraw Hill Publ. Co. Ltd.: New Delhi, India, 1979.

39. Mclaughlin, H. Characterizing Biochars prior to Addition to Soils-Version I. Alterna Biocarbon Inc. 2010, $333,334$.

40. Origin. OriginLab Corporation OriginPro; OriginLab: Northampton, MA, USA, 2021.

41. Naeem, M.A.; Khalid, M.; Aon, M.; Abbas, G.; Amjad, M.; Murtaza, B.; Khan, W.-U.-D.; Ahmad, N. Combined application of biochar with compost and fertilizer improves soil properties and grain yield of maize. J. Plant Nutr. 2018, 41, 112-122. [CrossRef]

42. Malik, A.U.; Singh, Z. Improved fruit retention, yield and fruit quality in mango with exogenous application of polyamines. Sci. Hortic. (Amst.) 2006, 110, 167-174. [CrossRef] 
43. Danish, S.; Zafar-ul-Hye, M. Combined role of ACC deaminase producing bacteria and biochar on cereals productivity under drought. Phyton 2020, 89, 217-227. [CrossRef]

44. Danish, S.; Zafar-ul-Hye, M.; Fahad, S.; Saud, S.; Brtnicky, M.; Hammerschmiedt, T.; Datta, R. Drought stress alleviation by ACC deaminase producing Achromobacterxylosoxidans and Enterobacter cloacae, with and without timber waste biochar in maize. Sustainability 2020, 12, 6286. [CrossRef]

45. Zafar-Ul-Hye, M.; Danish, S.; Abbas, M.; Ahmad, M.; Munir, T.M. ACC deaminase producing PGPR Bacillus amyloliquefaciens and agrobacterium fabrum along with biochar improve wheat productivity under drought stress. Agronomy 2019, 9, 343. [CrossRef]

46. Baiea, M.H.M.; El-Sharony, T.F.; Eman, A.A.; Moneim, A.E. Effect of different forms of potassium on growth, yield and fruit quality of mango cv. Hindi. Int. J. Chem.Tech. Res. 2015, 8, 1582-1587.

47. Eliwa, G.I. Effect of foliar spray of some micronutrients and Gibberellin on leaf mineral content, fruit set, yield and fruit quality of "Anna" apple trees. Alex. J. Agric. Res. 2003, 48, 137-143.

48. Deenik, J.L.; Cooney, M.J. The potential benefits and limitations of corn cob and sewage sludge biochars in an infertile Oxisol. Sustainability 2016, 8, 131. [CrossRef]

49. Gupta, R.K. Monika Biochar: Effects on crop productivity and soil properties. Int. J. Trop. Agric. 2016, 34, 1721-1729.

50. Younis, U.; Danish, S.; Malik, S.A.; Ahmed, N.; Munir, T.M.; Rasheed, M.K. Role of cotton sticks biochar in immobilization of nickel under induced toxicity condition and growth indices of Trigonellacorniculata L. Environ. Sci. Pollut. Res. 2020, 27, 1752-1761. [CrossRef] [PubMed]

51. Gunes, A.; Inal, A.; Taskin, M.B.; Sahin, O.; Kaya, E.C.; Atakol, A. Effect of phosphorus-enriched biochar and poultry manure on growth and mineral composition of lettuce (Lactuca sativa L. cv.) grown in alkaline soil. Soil Use Manag. 2014, 30, 182-188. [CrossRef]

52. Jasmitha, B.G.; Honnabyraiah, M.K.; Anil Kumar, S.; Swamy, G.S.K.; Patil, S.V.; Jayappa, J. Effect of enriched biochar on growth of mango seedlings in nursery. Int. J. Chem. Stud. 2018, 6, 415-417.

53. Dutta, P. Effect of foliar boron application on panicle growth, fruit retention and physico-chemical characters of mango cv. Himsagar. Indian J. Hortic. 2004, 61, 265-266.

54. Chen, Y.; Aviad, T. Effects of Humic Substances on Plant Growth. In Proceedings of the Humic Substances in Soil and Crop Sciences: Selected Readings; Soil Science Society of America; John Wiley \& Sons, Inc.: Madison, MI, USA, 1990; pp. 161-186.

55. Chan, K.Y.; Van Zwieten, L.; Meszaros, I.; Downie, A.; Joseph, S. Using poultry litter biochars as soil amendments. Soil Res. 2008, 46, 437. [CrossRef]

56. Ram, R.A.; Singha, A.; Singh, V.K. Improvement in yield and fruit quality of mango (Mangiferaindica) with organic amendments. Indian J. Agric. Sci. 2019, 89, 1429-1433.

57. Marschner, H. Marschner's Mineral Nutrition of Higher Plants, 3rd ed.; Marschner, P., Ed.; Academic Press: Cambridge, MA, USA, 2011.

58. Tohidloo, G.; Souri, M.K.; Eskandarpour, S. Growth and fruit biochemical characteristics of three strawberry genotypes under different potassium concentrations of nutrient solution. Open Agric. 2018, 3, 356-362. [CrossRef]

59. Danish, S.; Younis, U.; Nasreen, S.; Akhtar, N.; Iqbal, M.T. Biochar consequences on cations and anions of sandy soil. J. Biodivers. Environ. Sci. 2015, 6, 121-131.

60. Abd El-Mageed, T.A.; Abdurrahman, H.A.; Abd El-Mageed, S.A. Residual acidified biochar modulates growth, physiological responses, and water relations of maize (Zea mays) under heavy metal-contaminated irrigation water. Environ. Sci. Pollut. Res. 2020, 27, 22956-22966. [CrossRef] [PubMed]

61. Ali, S.; Noureen, S.; Shakoor, M.B.; Haroon, M.Y.; Rizwan, M.; Jilani, A.; Arif, M.S.; Khalil, U. Comparative evaluation of wheat straw and press mud biochars for $\mathrm{Cr}(\mathrm{VI})$ elimination from contaminated aqueous solution. Environ. Technol. Innov. 2020, 19, 101017. [CrossRef]

62. Suthar, R.G.; Wang, C.; Nunes, M.C.N.; Chen, J.; Sargent, S.A.; Bucklin, R.A.; Gao, B. Bamboo biochar pyrolyzed at low temperature improves tomato plant growth and fruit quality. Agriculture 2018, 8, 153. [CrossRef]

63. Beesley, L.; Moreno-Jiménez, E.; Gomez-Eyles, J.L.; Harris, E.; Robinson, B.; Sizmur, T. A review of biochars' potential role in the remediation, revegetation and restoration of contaminated soils. Environ. Pollut. 2011, 159, 3269-3282. [CrossRef]

64. Bruun, E.W.; Ambus, P.; Egsgaard, H.; Hauggaard-Nielsen, H. Effects of slow and fast pyrolysis biochar on soil C and N turnover dynamics. Soil Biol. Biochem. 2012, 46, 73-79. [CrossRef]

65. Major, J.; Rondon, M.; Molina, D.; Riha, S.J.; Lehmann, J. Maize yield and nutrition during 4 years after biochar application to a Colombian savanna oxisol. Plant Soil 2010, 333, 117-128. [CrossRef]

66. Mahmood, T.; Anwar, F.; Abbas, M.; Boyce, M.C.; Saari, N. Compositional variation in sugars and organic acids at different maturity stages in selected small fruits from Pakistan. Int. J. Mol. Sci. 2012, 13, 1380-1392. [CrossRef] [PubMed]

67. de Souza, V.R.; Pereira, P.A.P.; Teixeira, T.R.; da Silva, T.L.T.; Pio, R.; Queiroz, F. Influence of processing on the antioxidant capacity and bioactive compounds in jellies from different blackberry cultivars. Int. J. Food Sci. Technol. 2015, 50, 1658-1665. [CrossRef]

68. Abo-Ogiala, A.M.M.E. Impact of Biochar on Vegetative Parameters, Leaf Mineral Content, Yield and Fruit Quality of Grande Naine Banana in Saline-sodic Soil. Egypt. J. Hort. 2018, 45, 315-322. [CrossRef]

69. Zafar-ul-Hye, M.; Tahzeeb-ul-Hassan, M.; Abid, M.; Fahad, S.; Brtnicky, M.; Dokulilova, T.; Datta, R.; Danish, S. Potential role of compost mixed biochar with rhizobacteria in mitigating lead toxicity in spinach. Sci. Rep. 2020, 10, 12159. [CrossRef] [PubMed] 